\title{
Prediction of stand carbon (C) storage and net primary production (NPP) of secondary forests in subtropical China: the effect of climate change and its contribution to carbon neutrality in 2060
}

Jia Jin

Central South University of Forestry and Technology

Wenhua Xiang ( $\sim$ xiangwh2005@163.com )

Central South University of Forestry and Technology

Yelin Zeng

Central South University of Forestry and Technology

Shuai Ouyang

Central South University of Forestry and Technology

Xiaolu Zhou

Hunan Normal University

Yanting Hu

Central South University of Forestry and Technology

Zhonghui Zhao

Central South University of Forestry and Technology

Liang Chen

Central South University of Forestry and Technology

Pifeng Lei

Central South University of Forestry and Technology

Xiangwen Deng

Central South University of Forestry and Technology

Hui Wang

Chinese Academy of Forestry

Shirong Liu

Chinese Academy of Forestry

Changhui Peng

University of Quebec in Montreal: Universite du Quebec a Montreal

Research

Keywords: Carbon (C) storage, Climate change, Forest restoration, Net primary productivity (NPP), TRIPLEX model

Posted Date: November 8th, 2021

DOI: https://doi.org/10.21203/rs.3.rs-1031503/v1

License: (ㅇ) (1) This work is licensed under a Creative Commons Attribution 4.0 International License. Read Full License 


\section{Abstract \\ Background}

Forest ecosystems play an important role in carbon sequestration and climate change mitigation, as well as achieving target for carbon neutrality in 2060 proposed by the Chinese government. However, changes in carbon storage and net primary production in natural secondary forests stemming from tree growth and future climate change have not yet been investigated in subtropical areas in China with complex compositions of tree species. Here, we used data from inventory plots in four secondary forests (evergreen broad-leaved forest, deciduous and evergreen broad-leaved mixed forest, deciduous broad-leaved forest, and coniferous and broad-leaved mixed forest) at different restoration stages and run a hybrid model (TRIPLEX 1.6) to predict changes in stand carbon storage and net primary production under two future climate change scenarios (RCP4.5 and RCP8.5).

\section{Results}

There was a high correlation between predicted and observed values $\left(R^{2}>0.87\right)$ for average stand diameter at breast height $(1.3 \mathrm{~m})$, stand density, carbon storage, and net primary production in the four forests, indicating that the simulations by TRIPLEX1.6 were accurate. Net primary production was highest in deciduous and evergreen broad-leaved mixed forest $\left(3.95 \mathrm{t} \mathrm{ha}^{-1} \mathrm{yr}^{-1}\right.$ in 2030 and $3.81 \mathrm{t}$ $\mathrm{ha}^{-1} \mathrm{yr}^{-1}$ in 2060), indicating a high carbon storage capacity. Evergreen broad-leaved forest is the subtropical climax community and can store large amounts of carbon (85.22 $\mathrm{t} \mathrm{ha}^{-1}$ in 2030 and $135.76 \mathrm{t} \mathrm{ha}^{-1}$ in 2060). Net primary production in coniferous and broad-leaved mixed forests increased gradually over time but decreased over time in the other three forests. Net primary production was greater in young forest compared with mature forest. The effects of climate change (RCP4.5 and RCP8.5) on carbon storage significantly differed between coniferous and broad-leaved mixed forest and the other three forest types $(p<0.001)$.

\section{Conclusions}

Stand carbon storage of evergreen broad-leaved forest was predicted to be the largest. Nevertheless, the carbon sequestration potential under future climate change was still limited in the short and medium-term. The floristic composition and tree growth of existing forests should be properly managed in order to enhance carbon sequestration for climate change mitigation.

\section{Background}

Forests cover 4.03 billion hectares worldwide, which is about $30 \%$ of the terrestrial surface of our planet, and account for $45 \%$ of terrestrial carbon (C) and 75\% of terrestrial gross primary production (GPP) [], Forests play an important role in the global C cycle []. Vegetation net primary production (NPP) measures the direct production capacity of forest ecosystems and C sequestration efficiency in the terrestrial $\mathrm{C}$ cycle []. Attaining net zero emissions by mid-century will require all nations to comply with the objectives and principles laid out in the UN Framework Convention on Climate Change (UNFCCC) and its Paris Agreement. Accurate estimation of forest C storage and potential capacity is essential for achieving this goal. The current rate of change in global ecosystems is unprecedented. Forests can sequester $\mathrm{C}$ in ecosystems [3], and this is a safe and affordable strategy for mitigating the effects of climate change [. Recently, the Chinese government officially announced its goal to peak $\mathrm{CO}_{2}$ emissions before 2030 and achieve $\mathrm{C}$ neutrality in 2060 . There is thus an urgent need to determine how the NPP and C sequestration capability of forests might change in the future (especially in 2030 and 2060) under climate change.

Natural forest restoration is an effective approach for storing C [7]. On average, natural forests have 6 times and 40 times $C$ storage capacity of agroforests and plantations, respectively (sequestering 12, 1.9, and $0.3 \mathrm{Pg} \mathrm{C}$ per $100 \mathrm{M}$ ha by 2100 , respectively) [7]. Therefore, natural forest restoration on disturbed lands should be prioritized [7]. The most effective places for natural forest restoration for $\mathrm{C}$ storage are in the tropics and subtropics. Subtropical forests cover $11 \%$ of the land surface and store significant amounts of C [. There are also large areas of naturally restored young forest on bare land in mountainous areas [. Some evergreen broad-leaved forests (the climax vegetation) have been converted into secondary forests via anthropogenic disturbance $[7,10]$. Thus, subtropical secondary forests have become one of the most common types of natural forests and have a complex floristic composition and structure [. The $\mathrm{C}$ sequestration ability of plantations and some natural forests has been well characterized, but our knowledge of $\mathrm{C}$ sequestration in secondary forests is still limited and poorly quantified for the role in mitigating climate change [. 
Previous studies have shown that the $\mathrm{C}$ sequestration ability of forest ecosystems is affected by the interaction of various factors, such as forest origin, forest type, stand age, geography, and soil conditions []. The $\mathrm{C}$ sequestration capacity varies greatly among forest types [3]. C storage and NPP were significantly higher in broad-leaved forest than in mixed coniferous and broad-leaved forest in a subtropical area . Stand age affects forest $\mathrm{C}$ storage and is an important variable for predicting future $\mathrm{C}$ sequestration [14]. The growth of forests typically changes with forest age, and $\mathrm{C}$ stocks tend to be higher in old, complex forests $[12,14$,$] . Global climate change will affect the$ structure and functions of forest ecosystems []. According to the IPPC5, surface mean temperature is projected to increase in the subtropical region, and precipitation is projected to decrease (RCPs) [. Climate factors, such as temperature, and precipitation affect forest productivity, plant physiology, and community composition through the specific climatic constraints associated with different forests []. Consequently, there is much uncertainty in the direction and magnitude of these effects on different forests [20,]. More work is needed to investigate the ecosystem production and C storage capacity in subtropical secondary forests with different stand age and predict changes under future climate change conditions [25,]. Such work would aid the ability of forest managers to manage forests under future climate change [. Subtropical areas in the world vary in their climate. Subtropical China has a humid and warm climate because of the monsoon circulation and the Qinghai-Tibet Plateau, which contrasts with the extremely arid conditions in other subtropical areas around the world. Hunan is a typical subtropical area of China with various forests, most of which are secondary forests. These secondary forests are widespread in southern China [.

The $\mathrm{C}$ storage and net primary productivity (NPP) in forests can be estimated using conversion parameter estimation, remote sensing, and model simulation. The models for simulating $\mathrm{C}$ storage and productivity are grouped into empirical statistical models based on inventory data of stand characteristics and site conditions [], mechanistic models based on the interaction between the physiological process of forest growth and environmental factors [.], and hybrid models based on statistical experience, environmental change, and a combination of forest physiological and ecological processes [. The use of inventory, satellite, and field data for initialization, parameterization, and validation in process-based hybrid models is a promising approach for regional estimation and prediction in future and climate change [,]. TRIPLEX1.6 is a hybrid model [34] with simple inputs and high simulation accuracy [. Compared with models that have been developed with a static climate or the classical assumption of stable site conditions, the TRIPLEX1.6 model can project the impact of climate change. Therefore, the TRIPLEX1.6 model is a suitable methods for simulating and predicting C storage and NPP in subtropical secondary forest under future climate change.

The aim of this study was to provide data that could help forest managers work towards achieving the $C$ neutrality target in 2060 . We used both forest inventory plots data and the TRIPLEX1.6 model to simulate the stand C storage and NPP of subtropical secondary forests and predict the effects of two future climate change scenarios (RCP4.5 and RCP8.5) on stand C storage and NPP in different forest types. Specifically, the objectives of this study were to (1) characterize differences in C storage and NPP among forest types; (2) predict stand C storage and NPP in different forest types in 2030 and 2060; and (3) quantifying the impacts of climate change (RCP4.5 and RCP8.5) on C storage and NPP secondary forests in 2030 and 2060.

\section{Results}

\section{TIPLEX1.6 model validation}

We used 290 forest stands in this study according to the proportion of different forest types to validate the TRIPLEX1.6 model. The simulated values were compared against the observations of all secondary forests to test the prediction accuracy of the model. There were high correlations between the simulated and observed values for stem density $\left(R^{2}=0.9963, p<0.01\right)$, stand average $\mathrm{DBH}\left(R^{2}=\right.$ $0.9656, p<0.01)$, stand C storage $\left(R^{2}=0.8742, p<0.01\right)$, and NPP $\left(R^{2}=0.9424, p<0.01\right)$ in all forest stands (Fig. 1$)$.

\section{Dynamics of stand $C$ storage and NPP with stand age among secondary forests}

Simulations and predictions of TRIPLEX1.6 revealed the dynamics of stand C storage and NPP among secondary forest types over 100 years (Fig. 2). Overall, the results showed that there were significant differences in stand C storage and NPP between coniferous and broad-leaved mixed forest and the three other subtropical secondary forests. Stand C storage gradually increased in all forests in 100 years, whereas the stand $\mathrm{C}$ storage of coniferous and broad-leaved forest was significantly lower than that of the other three forests. The dynamics of stand NPP revealed a difference in the growth rate of $\mathrm{C}$ storage among secondary forests. The NPP of three broad-leaved forests peaked in approximately 25 years and then decreased gradually over time, whereas the NPP of coniferous and broad-leaved 
forest increased for 50 years and then stabilized. The NPP was significantly lower in coniferous and broad-leaved mixed forest than in the other three forests.

As the forest developed, the age composition gradually changed from young to mature and over-mature forest. We then predicted the $\mathrm{C}$ storage and NPP among secondary forests across the age groups from 2014 to 2060 (Fig. 3 and 4). C storage of over-mature forest was consistently the highest in all age groups among the different forest types, and the $\mathrm{C}$ storage across all age groups gradually increased. The NPP of young forest in the three broad-leaved forests was the highest in all age groups and then decreased over time (the young forest in deciduous forest could not be well fitted); the NPP of mature forest in coniferous and broad-leaved mixed forest was the highest and then increased over time.

\section{Effects of climatic change on stand C storage and NPP in secondary forests}

We predicted stand $\mathrm{C}$ storage and the difference in NPP between current and future climate scenarios (RCP4.5 and RCP8.5) among secondary forests (Table 1). We found that future climate changes were predicted to result in increased stand $\mathrm{C}$ storage and NPP for all subtropical forests. Overall, the response under RCP8.5 and RCP4.5 was the same. Under the same climate scenario, the response of NPP in forests in 2030 was stronger than that in 2060. The response of stand C storage and NPP of the four forest types under the climate scenarios differed. The difference in stand $\mathrm{C}$ storage for coniferous and broad-leaved mixed forest was significantly lower compared with that for the other three forests $(p<0.001)$ (Table 1). The difference in NPP for evergreen broad-leaved forest and coniferous and broad-leaved mixed forest was significantly lower than that for deciduous forest and deciduous broad-leaved and evergreen broad-leaved mixed forests $(p<0.001)$ (Table 1).

Table 1

The differences in $\mathrm{C}$ storage ( $\mathrm{C} \mathrm{ha}^{-1}$ ) and NPP $\left(\mathrm{t} \mathrm{ha}^{-1} \mathrm{yr}^{-1}\right)$ (mean \pm standard deviation) of four subtropical secondary forests calculated in 2030 and 2060 between current and the future climate scenarios (RCP4.5 and RCP8.5, $p<0.001$ ). EBF = evergreen broad-leaved forest, DEF = deciduous and evergreen broad-leaved mixed forest, DBF = deciduous broad-leaved forest, and CDF = coniferous and broad-leaved mixed forest. Different letters in the same column indicate significant differences $(p<0.001)$, and the same letters indicate no significant differences.

\begin{tabular}{|c|c|c|c|c|c|c|c|c|}
\hline \multirow[t]{2}{*}{ Forest type } & \multicolumn{2}{|c|}{ C storage in 2030} & \multicolumn{2}{|c|}{ C storage in 2060} & \multicolumn{2}{|l|}{ NPP in 2030} & \multicolumn{2}{|l|}{ NPP in 2060} \\
\hline & RCP4.5 & RCP8.5 & RCP4.5 & RCP8.5 & RCP4.5 & RCP8.5 & RCP4.5 & RCP8.5 \\
\hline EBF & $4.33 \pm 0.45^{a}$ & $4.33 \pm 0.45^{a}$ & $5.87 \pm 0.57^{a}$ & $6.41 \pm 0.63^{a}$ & $0.13 \pm 0.02^{b}$ & $0.14 \pm 0.02^{b}$ & $0.09 \pm 0.01^{b}$ & $0.10 \pm 0.01^{b}$ \\
\hline DEF & $4.47 \pm 0.78^{a}$ & $4.47 \pm 0.78^{a}$ & $6.81 \pm 0.97^{a}$ & $7.54 \pm 0.99^{a}$ & $0.20 \pm 0.01^{a}$ & $0.22 \pm 0.01^{a}$ & $0.15 \pm 0.01^{a}$ & $0.17 \pm 0.01^{a}$ \\
\hline DBF & $4.62 \pm 0.32^{a}$ & $4.62 \pm 0.32^{\mathrm{a}}$ & $7.31 \pm 0.54^{a}$ & $8.13 \pm 0.92^{\mathrm{a}}$ & $0.20 \pm 0.01^{a}$ & $0.22 \pm 0.01^{a}$ & $0.17 \pm 0.01^{a}$ & $0.18 \pm 0.05^{a}$ \\
\hline CDF & $2.11 \pm 0.11^{b}$ & $2.11 \pm 0.11^{b}$ & $3.71 \pm 0.15^{\mathrm{b}}$ & $4.15 \pm 0.16^{b}$ & $0.10 \pm 0.01^{b}$ & $0.12 \pm 0.01^{b}$ & $0.10 \pm 0.00^{b}$ & $0.11 \pm 0.00^{\mathrm{b}}$ \\
\hline
\end{tabular}

\section{Prediction of the stand C storage and NPP of secondary forests in 2030 and 2060}

Overall, the average stand C storage of subtropical secondary forests is expected to reach $65.74 \mathrm{t} \mathrm{C} \mathrm{ha}^{-1}$ in 2030 and $^{113.71} \mathrm{t} \mathrm{C} \mathrm{ha-1} \mathrm{in}$ 2060. To understand the role of the four subtropical secondary forests in reaching targets of having $\mathrm{CO}_{2}$ emissions peak in 2030 and achieving C neutrality in 2060, stand C storage and NPP of the four forest types under the three climate scenarios (current, RCP4.5, and RCP8.5) were predicted (Table 2). Under all climate scenarios, stand C storage was the highest in evergreen broad-leaved forest and smallest in coniferous and broad-leaved forest. The growth rate of $\mathrm{C}$ storage was the fastest in deciduous and evergreen broad-leaved mixed forest from 2014 to 2030 and in coniferous and broad-leaved mixed forest from 2030 to 2060 . NPP was highest in deciduous and evergreen broad-leaved mixed forest and lowest in coniferous and broad-leaved forest. 
Table 2

C storage $\left(\mathrm{t} \mathrm{C} \mathrm{ha}^{-1}\right), \mathrm{C}$ storage growth rate (\%), and NPP $\left(\mathrm{t} \mathrm{ha}^{-1} \mathrm{yr}^{-1}\right)$ in the four subtropical secondary forests predicted under current and future climate scenarios (RCP4.5 and RCP8.5) in 2014, 2030, and 2060. EBF = evergreen broad-leaved forest, DEF = deciduous and evergreen broad-leaved mixed forest, DBF = deciduous broad-leaved forest, and CDF = coniferous and broad-leaved mixed forest.

\begin{tabular}{|c|c|c|c|c|c|c|c|c|c|}
\hline \multirow{2}{*}{$\begin{array}{l}\text { Forest } \\
\text { type }\end{array}$} & \multirow{2}{*}{$\begin{array}{l}\text { Climate } \\
\text { scenario }\end{array}$} & \multicolumn{2}{|l|}{2014} & \multicolumn{3}{|l|}{2030} & \multicolumn{3}{|l|}{2060} \\
\hline & & C storage & NPP & C storage & $\begin{array}{l}\text { C } \\
\text { storage } \\
\text { growth } \\
\text { rate }\end{array}$ & NPP & C storage & $\begin{array}{l}\text { C } \\
\text { storage } \\
\text { growth } \\
\text { rate }\end{array}$ & NPP \\
\hline EBF & Current & $55.50 \pm 41.57$ & $3.86 \pm 1.36$ & $85.22 \pm 44.47$ & $53.55 \%$ & $3.83 \pm 1.23$ & $135.76 \pm 51.01$ & $59.31 \%$ & $3.59 \pm 0.80$ \\
\hline DEF & & $41.09 \pm 32.69$ & $4.09 \pm 1.87$ & $77.34 \pm 25.16$ & $88.22 \%$ & $3.95 \pm 0.25$ & $129.57 \pm 24.95$ & $67.53 \%$ & $3.81 \pm 0.24$ \\
\hline DBF & & $40.37 \pm 27.41$ & $3.87 \pm 1.47$ & $69.21 \pm 34.58$ & $71.44 \%$ & $3.78 \pm 1.06$ & $119.05 \pm 46.53$ & $72.01 \%$ & $3.75 \pm 0.91$ \\
\hline CDF & & $28.14 \pm 15.60$ & $2.36 \pm 0.97$ & $50.57 \pm 21.24$ & $79.71 \%$ & $3.04 \pm 0.91$ & $93.54 \pm 29.35$ & $84.97 \%$ & $3.25 \pm 0.66$ \\
\hline Average & & $37.12 \pm 28.56$ & $3.29 \pm 1.29$ & $65.74 \pm 31.21$ & $77.10 \%$ & $3.54 \pm 0.97$ & $113.71 \pm 38.70$ & $72.97 \%$ & $3.54 \pm 0.69$ \\
\hline EBF & RCP4.5 & - & - & $88.56 \pm 47.29$ & $59.57 \%$ & $3.91 \pm 1.13$ & $138.63 \pm 54.15$ & $62.67 \%$ & $3.68 \pm 0.81$ \\
\hline DEF & & - & - & $81.81 \pm 25.50$ & $99.10 \%$ & $4.15 \pm 0.24$ & $136.38 \pm 25.32$ & $76.34 \%$ & $3.96 \pm 0.24$ \\
\hline DBF & & - & - & $74.88 \pm 38.21$ & $85.48 \%$ & $4.03 \pm 1.41$ & $129.36 \pm 51.54$ & $86.91 \%$ & $3.92 \pm 1.00$ \\
\hline CDF & & - & - & $52.69 \pm 22.96$ & $87.24 \%$ & $3.15 \pm 0.97$ & $97.40 \pm 31.71$ & $92.60 \%$ & $3.35 \pm 0.69$ \\
\hline Average & & - & - & $69.26 \pm 33.40$ & $86.58 \%$ & $3.69 \pm 1.05$ & $119.27 \pm 41.62$ & $81.43 \%$ & $3.67 \pm 0.73$ \\
\hline EBF & RCP8.5 & - & - & $88.57 \pm 47.57$ & $59.59 \%$ & $3.92 \pm 1.14$ & $139.17 \pm 54.46$ & $63.31 \%$ & $3.69 \pm 0.81$ \\
\hline DEF & & - & - & $82.31 \pm 25.76$ & $100.32 \%$ & $4.16 \pm 0.24$ & $137.11 \pm 25.62$ & $77.28 \%$ & $3.98 \pm 0.24$ \\
\hline DBF & & - & - & $75.41 \pm 38.63$ & $86.80 \%$ & $4.05 \pm 1.42$ & $130.19 \pm 52.11$ & $88.11 \%$ & $3.90 \pm 1.01$ \\
\hline CDF & & - & - & $52.94 \pm 23.11$ & $88.13 \%$ & $3.16 \pm 0.97$ & $97.84 \pm 31.90$ & $93.47 \%$ & $3.36 \pm 0.69$ \\
\hline Average & & - & - & $69.65 \pm 33.67$ & $87.63 \%$ & $3.70 \pm 1.05$ & $119.87 \pm 41.97$ & $82.34 \%$ & $3.68 \pm 0.74$ \\
\hline
\end{tabular}

\section{Discussion}

\section{C sequestration capacity of subtropical secondary forests}

Stand C storage in all forests increases gradually with stand growth; however, the $\mathrm{C}$ sequestration capacity of subtropical secondary forests varies at different restoration stages. Predictions of the stand $C$ storage in 2060 by the TRIPLEX1. 6 model indicated that the stand $\mathrm{C}$ storage of the evergreen broad-leaved forest was greater than that of the coniferous and broad-leaved mixed forest. Similar results were obtained in Jiangxi and Hunan [15,30]. Previous studies that have measured the biomass of permanent forest plots in subtropical forest [] have suggested that the above-ground biomass of subtropical old-growth evergreen broad-leaved forest in China is 210-230 $\mathrm{t} \mathrm{ha}^{-1} \mathrm{Z}$. This value is consistent with our simulated values of $\mathrm{C}$ storage using a conversion coefficient of 0.5 . The above findings indicate that evergreen broad-leaved forest plays an important role in forest $\mathrm{C}$ storage and productivity in subtropical areas. The key role of these late restoration stage forests in maintaining $\mathrm{C}$ stocks by preventing emissions derived from deforestation, forest degradation, and future climate warming emphasizes the need for habitat protection and sustainable management of complex and heterogeneous subtropical secondary forests [3].

There were also differences in the rate of $\mathrm{C}$ production among forest types. The increasing trend of NPP in coniferous and broad-leaved mixed forest as forests increased in age indicated that these forest types are interdependent or show complementary environmental adaptations that result in higher resource utilization efficiency; improved use of their individual niches might also explain why the NPP in these forests is increasing []. These findings indicate that coniferous and broad-leaved mixed forests have the potential to support high $\mathrm{C}$ productivity. However, in most secondary forests, $\mathrm{C}$ stocks typically increase rapidly during the initial phase of regeneration and then decelerate over subsequent decades and even centuries as primary forest species gradually colonize the area and grow to maturity []. The maximum NPP of evergreen broad-leaved forest occurred earlier compared with that of other forests because more productive forests show an earlier growth peak [. Previous studies indicate that NPP generally decreases in old forests to about half or one-third of 
its maximum value; other researchers have found old forests to be as productive as young forest stands [15]. In our study, the predicted NPP of old forests (100 years) decreased by $7.77-16.50 \%$ from its peak for all forest types except coniferous and deciduous broadleaved mixed forest. The continual recruitment of younger trees and rapid leaf area replacement, the compensatory growth of remaining vegetation, and canopy structural heterogeneity may offset this decrease in NPP in the moderately disturbed forests in this study [12]. These results indicate that subtropical secondary forests in China still have high potential for $\mathrm{C}$ sequestration compared with other forests.

The study of $\mathrm{C}$ sequestration in secondary forests is particularly important given that the proportion of secondary subtropical forests is projected to continue to increase because of increases in anthropogenic and environmental disturbances [7,44]. Previous research has shown that the greater amount of $\mathrm{C}$ in primary forest compared with secondary forest stems in large part to the difference in the number of large trees [44]. Hence, the natural regeneration of forests is the cheapest and technically easiest option for achieving targets of having $\mathrm{CO}_{2}$ emissions peak in 2030 and reaching $\mathrm{C}$ neutrality in 2060. Protecting woodland from fire and other human disturbances allows trees to return and forests to flourish; it also allows $\mathrm{C}$ stocks to build rapidly and reach the level of $\mathrm{C}$ storage of a mature forest in roughly 70 years [7]. The protection of subtropical natural secondary forest not only involves restoring it to the state of mature forest but also altering forest structure and composition so that it has a more stable $\mathrm{C}$ sequestration capacity similar to evergreen broad-leaved forest.

\section{Responses of stand C storage and NPP in subtropical forests to climate change}

We compared the stand C storage and NPP between future climate change (RCP4.5 and 8.5) and the current state in 2030 and 2060. Climate change had a positive effect on forest $\mathrm{C}$ storage, and this might be explained by the fact that higher water availability (precipitation) and heat (temperature) can promote vegetation productivity [20,]. Nevertheless, the $\mathrm{C}$ sequestration potential under future climate change was still limited in the short and medium-term. This response of $\mathrm{C}$ storage to climate change is consistent with previous studies [,]. Stand C storage and NPP significantly differed across forest types $(p<0.001)$. Climate change responses of forests were more sensitive in the middle of recovery, and this result is consistent with Wu et al. [49]. This might be driven by species-specific physiological characteristics and site conditions [28,]. Under disturbances or environmental changes, species asynchrony, facilitation, and species interactions might be the main drivers of ecosystem stability [11,]. Differences in the response of forest types and species to climate change contribute to forest community composition. Hence, understanding these differences would aid the development of measures for mitigating the negative effects of climate change, such as changes in stand structural attributes [49].

\section{Model evaluation, limitations, and uncertainty}

We calibrated and validated the TRIPLEX1.6 model with 290 permanent forest plot records in 2014 to obtain the optimal parameters for evergreen broad-leaved forest, deciduous and evergreen broad-leaved mixed forest, deciduous forests, and coniferous and broad-leaved mixed forest, which are four types of subtropical natural secondary forests in southern China. Our focus in adjusting model parameters was on the initial value of soil parameters. Soil fertility is an important initial input variable [20]. The initial value should be set based on the growth of the forest, the thickness of the humus layer observed in the field, and the degree of stress that the soil has experienced in the past. Although reference values are provided in previous studies, subtropical ecosystems are vulnerable to extreme climate events caused by global warming [. For example, the heavy snow/ice event that occurred in 2008 in southern China severely damaged forest ecosystems and resulted in decreased soil fertility. Therefore, the effect of historical natural disasters should be considered when setting the initial value of soil fertility. High consistency between the observed and simulated data from the model was achieved via model parameterization and repetitious adjustments.

Our prediction of $\mathrm{C}$ storage indicates that it will accumulate gradually with forest growth, and changes in NPP among subtropical secondary forests were consistent with those reported in previous studies [15,]. All stand variables had $R^{2}$ values of 0.87-0.99, which indicated that they could be used to predict growth $C$ dynamics across various stand ages. These findings of model performance are consistent with previous studies showing that the TRIPLEX1.6 model is robust and can be used to predict the growth of subtropical natural secondary forests and artificial forests, including $C$. lanceolata and $P$. massoniana in southern and southeast China with $R^{2}$ values of 0.94 for total biomass $C$ [36] and 0.91 for total biomass [37]. These findings, combined with previous simulation results of coniferous forests, indicated that the TRIPLEX1.6 model could simulate forest growth with a high level of accuracy for all forest types in subtropical China. 
The high biophysical heterogeneity and large amount of young age group subtropical secondary forests in subtropical China have increased the difficulty of evaluating the role of stand C storage and NPP in subtropical forests [53,]. Because of data limitations, the renewal of natural forest and under story regeneration in secondary forests was not considered in this study, which might reduce the robustness of our simulation results. Subtropical secondary forest has a high $\mathrm{C}$ sequestration capacity. In this study, the existing area of vegetation was not considered. Accurate prediction of spatial distributions is a major challenge and an important topic that should be examined in future studies. TRIPLEX1.6 simulations do not consider several variables related to contingency factors (i.e., anthropogenic disturbances, infestations, and extreme weather), which decreases their accuracy [35]. Despite these uncertainties, the TRIPLEX1.6 model suggests that the secondary forests in subtropical China have a high capacity for $\mathrm{C}$ sequestration and storage, but the effects of climate change (RCP4.5 and RCP8.5) on stand C storage and NPP differ among forest types.

\section{Conclusions}

We used inventory plots data at different restoration stages and hybrid model of TRIPLEX 1.6 to predict changes in stand C storage and NPP under the two climate change scenarios (RCP4.5 and RCP8.5). Stand C storage of evergreen broad-leaved forest was predicted to be the largest, and the NPP of deciduous and evergreen broad-leaved mixed forest was predicted to be the highest. The NPP in coniferous and broad-leaved mixed forest increased gradually over time and showed strong $\mathrm{C}$ storage potential capacity. There was a significant difference in the effects of climate change (RCP4.5 and RCP8.5) on stand C storage between coniferous and broad-leaved mixed forest and the other three forest types. These results indicate that the role of the floristic composition and tree growth of existing forests should be considered by forest managers for increasing $\mathrm{C}$ sequestration in secondary forests.

\section{Material And Methods Study area}

This study was carried out in Hunan Province $\left(24^{\circ} 38^{\prime}-30^{\circ} 08^{\prime} \mathrm{N}\right.$ and $108^{\circ} 47^{\prime}-114^{\circ} 15^{\prime} \mathrm{E}$, Fig. 1$)$ in central subtropical China. This province features mountains in the east, south, and west with elevations ranging from 25 to $1726 \mathrm{~m}$ (Fig. 5), hills in the east-central region, and plains in the northeast region surrounding Dongting Lake. The topography is heterogeneous, with slopes between $0^{\circ}$ and $70^{\circ}$. The total land area is 21.18 million ha, including 12.53 million ha of forests, 3.92 million ha of arable land, 1.2 million ha of land covered by water bodies, and 1.0 million ha of developed land.

This region has a continental and subtropical humid monsoon climate that is rich in light, heat, and water resources (Fig. 6). The mean annual rainfall is $1500 \mathrm{~mm}$, with $75 \%$ falling between March and August. The mean annual temperature is $14.1^{\circ} \mathrm{C}$. Annual climate changes are large: summers are hot, and winters are short and cold. The soil types include red soil, yellow soil, and red-yellow soil, with small areas of calcareous soil, purple soil, moisture soil, and mountain meadow soil (Fig. 6), which are mainly developed from granite, limestone, and shale.

\section{Forest types and stand age groups}

The National Forest Inventory of China classified subtropical forests into four forest types according to the dominant tree species: pine forest, fir forest, deciduous forest, and evergreen broadleaved forest [. These forest types encompass most but not all wide spread tree species in Hunan. Deciduous and evergreen broad-leaved mixed forests are an important forest type in the restoration process that have not been examined extensively in previous studies because of the difficulty of determining the dominant tree species and stand structure. Thus, we divided subtropical secondary forest into four forest types: coniferous and broad-leaved mixed forest, deciduous forest, deciduous and evergreen broad-leaved mixed forests, and evergreen broad-leaved forest. Forest type identification was based on the technical regulations for continuous forest inventory: coniferous or broad-leaved species accounted for less than $70 \%$ of the species in coniferous and broad-leaved mixed forest; the proportion of broad-leaved trees accounted for more than $70 \%$ of the species in broadleaved forest; and the proportion of all broad-leaved species accounted for less than $70 \%$ of the species in deciduous and evergreen broad-leaved mixed forests [. Among the natural secondary forests in Hunan, coniferous and broad-leaved mixed forests are mainly dominated by Pinus massoniana forests; the deciduous broad-leaved forests are mainly dominated by Alniphyllum fortunei, Choerospondias axillaris, and Liquidambar formosana. Hance; and tree species in the evergreen broad-leaved forests are mainly dominated by Cyclobalanopsis glauca Thunb, Litsea coreana Levl. var. sinensis, and Schima superba Gardn.

The study area is composed of subtropical natural uneven-aged forest. Therefore, five of the largest trees outside each plot were selected for stem core sampling, and the ring counts of these five tree samples were averaged to estimate stand age [13]. According to the 
forestry standards of China, the age composition of four forest types can be divided into young forest, middle-aged forest, premature forest, mature forest, and over-mature forest. The age group of the two mixed forests was determined by the age group of the dominant tree species and their growth condition (An additional table file shows this in more detail [see Additional file A]).

\section{TRIPLEX1.6 model description}

TRIPLEX is a hybrid model (An additional table file shows this in more detail [see Additional file B]) that integrates three well-established process-based sub-models: the forest production sub-model 3-PG [, the forest growth and yield sub-model TREEDYN3.0 [31], and the soil-C, soil-N (nitrogen) and soil-water-balance sub-model CENTURY4.0 []. The forest production sub-model estimates monthly gross primary productivity (GPP, including above- and below-ground biomass) from photosynthetic active radiation (PAR), mean air temperature, vapor pressure deficit (VPD), soil water, the percentage of frost days, and the leaf area index. The forest growth and yield sub-model calculates tree growth and yield variables (height, diameter at breast height $(1.3 \mathrm{~cm}, \mathrm{DBH}))$ using a function of the stem wood biomass increment [31]. The soil C, soil N, and soil-water balance sub-model simulate soil $\mathrm{C}$ and $\mathrm{N}$ dynamics between litter and soil pools, simulate water balances and dynamics, and calculate monthly water loss through transpiration, evaporation, soil water content, and snow water content [58]. TRIPLEX combines empirical and mechanistic components that can simulate various growth volumes in forest ecosystems using input data derived from site, soil, climate, and stand growth [34]. The hybrid model compensates for the inability of simplified growth models to take into account soil factors, feedback between the forest ground and underground, and climate impacts. The simulation of the TRIPLEX model involves key processes and dynamics including PAR, GPP, forest growth, biomass, soil C, soil nitrogen, and soil water [38]. After the model was optimized to version 1.6, a reasonable and balanced parameter generalization procedure that did not lead to a significant reduction of model accuracy but increased model practicability was described [38]

The TRIPLEX1.6 simulation requires input data such as latitude, longitude, soil texture, monthly climate records, tree species physiological variables (such as maximum tree height and diameter), tree species process mediators, stand structure, and certain initial site conditions. Simulation outputs include tree diameter, height, basal area, total volume, leaf area index, GPP, net ecosystem production (NEP), biomass, soil C, and N and water dynamics. TRIPLEX1.6 has been tested and applied to forest growth and biomass production on a regional scale at Zhejiang Province, China [37,] and northeastern China [35] and has also been used to predict Cunninghamia lanceolata and P. massoniana stand production in Hunan Province, China [36]. Natural secondary forests in a subtropical region were examined in this paper, and the suitability of the model in the subtropical region has been demonstrated by previous studies [36].

\section{Model input data}

There were five primary data sources: permanent forest-plot $\left(667 \mathrm{~m}^{2}\right)$ records taken from the forest inventory, climate datasets, field observations, the literature, and assumptions. The permanent forest plot database is a well-designed forest inventory program built from data acquired at 5-year intervals beginning in 1973. Field investigations in the permanent forest plot database include records of location, site conditions, and DBH of each tree; average stand height प; and land use, site class, dominant tree species, stand density, age, average DBH, average tree height, and volume [. Plots included at least one of the four forest types and met the criteria for tree size (e.g., $\mathrm{DBH} \geq 5.0 \mathrm{~cm}$ ) and stage of stand development (with the exception of seedlings). Plots were required to meet various criteria regarding site, climate, and growth, and the initial data needed to be detailed and representative of the forest types, as well as of the study area as a whole [36]. According to the forest plot database, stand biomass can be estimated using allometric equations [43] (An additional table file shows this in more detail [see Additional file C]) for the main subtropical tree species. The conversion parameter between biomass and $\mathrm{C}$ storage was 0.5 . Based on data collected in 2009 and 2014, we calculated average annual NPP $\left(\mathrm{t} \mathrm{ha}^{-1} \mathrm{yr}^{-1}\right)$ using the following formula:

$$
N P P=\frac{B_{t 2}-B_{t 1}}{t_{2}-t_{1}}
$$

where $B_{t 1}$ and $B_{t 2}$ are the plot biomass in year $\mathrm{t}_{1}(2009)$ and $\mathrm{t}_{2}$ (2014), respectively.

Climate data for each permanent plot were interpolated from data collected from meteorological stations [36]. The data recorded between 2005 and 2014 were used as climate inputs for each plot. The climate inputs were monthly frost days, monthly average air temperature, monthly sum of precipitation, and the monthly average atmospheric VPD [34]. Atmospheric N deposition was set to $18 \mathrm{~kg} N$ $\mathrm{ha}^{-1}$ year $^{-1}$ [55]. Field observations were made at independent sampling plots in Hunan Province. The choice of reference literature and assumptions were based on indicator functions for the four forest types selected for this study [,]. 
Predictors for the TRIPLEX1.6 model were climate normal from the 96 automatic meteorological monitoring stations in Hunan Province for current (2005-2014) and future (2015-2060) periods. The future climate change scenario data were derived from the WCRP's CMIP5 multi-model dataset provided by the National Climate Center of China Meteorological Administration (http://www.climatechangedata.cn). According to the fifth report of the IPCC, we obtained data for current scenarios, RCP4.5 (medium emissions scenario), and RCP8.5 (high emissions scenario) to simulate the responses of different forest types and forest divisions to future climate change. Because the CMIP5 GCMs have different horizontal resolutions, future climate data were interpolated on a common $1^{\circ} \times 1^{\circ}$ grid using the nearest neighbor interpolation method.

\section{Model initialization, parameterization, and simulations}

From the initial modelling, we examined the most sensitive parameters through direct measurement, literature searches, default values, and statistical fitting. To simulate forest ecosystem processes and dynamics, TRIPLEX1.6 requires some initial values of stand variables describing conditions of forest stands and soils. There are three key variables (stand density, tree height, and DBH) related to initial conditions for forest growth and yield simulation [38]. To ensure the robustness of the TRIPLEX1.6 model, most of the general and nonspecific site parameters were derived from previous studies. These include PAR parameters; the minimum, maximum, and optimum temperature for tree growth; stomata and canopy conductance; initial $\mathrm{N}$ for tree growth; the lignin-nitrogen ratio and lignin fraction of leaf and fine and coarse roots; and the fraction of soil water flow [37]. Several new parameters such as wood C density, specific leaf area (SLA), mortality, the fraction of leaf, branch, wood, and coarse and fine roots were used and adjusted from default model values to better represent the forest ecosystems of subtropical China for this study (An additional table file shows this in more detail [see Additional file $D$ and $E])$.

TRIPLEX1.6 was calibrated by randomly selecting one-third of each forest type and validated by remainder data before simulation runs. The simulation was executed for DBH, stem density, C storage, and NPP. We simulated each stand from its respective year of regeneration to 2014, at which point all simulations across all stands within the natural subtropical forest region were summed. The same procedure was followed for all model runs by Zhou et al [38].

\section{Abbreviations}

\begin{tabular}{|ll|}
\hline Abbreviations & Descriptions \\
\hline C & Carbon \\
\hline NPP & Nitrogen \\
\hline NEP & Net primary productivity \\
\hline GPP & Net ecosystem production \\
\hline PAR & Gross primary productivity \\
\hline VPD & Photosynthetic active radiation \\
\hline DBH & Vapor pressure deficit \\
\hline PSP & Diameter at breast height (1.3cm) \\
\hline EBF & Permanent sample plots \\
\hline DEF & Deciduous and evergreen broad-leaved mixed forest \\
\hline DBF & Deciduous broad-leaved forest \\
\hline CDF & Conifer and broad-leaved mixed forest \\
\hline UNFCCC & UN Framework Convention on Climate Change \\
\hline
\end{tabular}

\section{Declarations}

Availability of data and materials

Page 9/19 
All data parameters about the TRIPLEX1.6 model on all of the conclusions of the manuscript rely to be presented in the additional supporting files. And the statistical parameters of sample plot data and climatic conditions and calculation method of forest vegetation carbon are also mentioned in the additional supporting files.

\section{Acknowledgements}

We thank the professional English editing team from the Charlesworth Group (see https://www.cwauthors.com.cn ) to improve the language of this manuscript.

\section{Funding}

This study was supported by the Key Research and Development Program of Hunan Province; the National Key Research and Development Program of China (2016YFD0600202); and the Huitong Forest Ecological Station funded by the National Forestry and Grassland Administration of China (2021132078).

\section{Authors' information}

\section{Affiliations}

Faculty of Life Science and Technology, Central South University of Forestry and Technology, Changsha, Hunan, 410004, China Jin Jia, Wenhua Xiang, Yelin Zeng, Shuai Ouyang, Yanting Hu, Zhonghui Zhao, Liang Chen, Pifeng Lei\& Xiangwen Deng

Huitong National Station for Scientific Observation and Research of Chinese Fir Plantation Ecosystems in Hunan Province, Huitong, Hunan, 438107, China

Jin Jia, Wenhua Xiang, Shuai Ouyang, Yanting Hu, Zhonghui Zhao, Liang Chen, Pifeng Lei\& Xiangwen Deng

School of Geographic Sciences, Hunan Normal University, Changsha 410081, China

Xiaolu Zhou \& Changhui Peng

Research Institute of Forest Ecology, Environment and Protection, Chinese Academy of Forestry, Beijing 100091, China

Hui Wang\& Shirong Liu

Institute of Environment Sciences, Department of Biological Sciences, University of Quebec at Montreal, Montreal, QC H3C 3P8, Canada

Changhui Peng

\section{Contributions}

W.H.X. planned and designed the research. J.J., W.X.H., Y.L.Z., S.O.Y, Y.T.H., Z.H.Z., L.C., X.W.D., and X.L.Z. performed experiments, collected and analyzed data, and conducted model simulations. J.J., W.X.H., Y.L.Z., S.O.Y, P.F.L., X.L.Z., H.W., S.R.L., and C.H.P. wrote and edited the manuscript.

Corresponding author

Correspondence to Wenhua Xiang.

Ethics declarations

Ethics approval and consent to participate

Not applicable.

\section{Consent for publication}

Not applicable. 
The authors declare that they have no competing interests.

\section{References}

1. Li Z, Chen Y, Zhang Q, Li Y. Spatial patterns of vegetation carbon sinks and sources under water constraint in Central Asia. Journal of Hydrology. 2020; 590: 125355. https://doi.org/10.1016/j.jhydrol.2020.125355.

2. Pan YD, Birdsey RA, Phillips OL, Jackson RB. The structure, distribution, and biomass of the world's forests. Annual Review of Ecology, Evolution, and Systematics. 2013; 44: 593-622. https://doi.org/10.1146/annurev-ecolsys-110512-135914.

3. Bordin KM, Esquivel-Muelbert A, Bergamin RS, Klipel J, Picolotto RC, Frangipani MA, Müller SC. Climate and large-sized trees, but not diversity, drive above-ground biomass in subtropical forests. Forest Ecology and Management. 2021; 490:

119126. https://doi.org/10.1016/j.foreco.2021.119126.

4. Siddiq Z, Hayyat MU, Khan AU, Mahmood R, Shahzad L, Ghaffar R, Cao KF. Models to estimate the above and below ground carbon stocks from a subtropical scrub forest of Pakistan. Global Ecology and Conservation. 2021; 27:

e01539. https://doi.org/10.1016/j.gecco.2021.e01539.

5. Bao G, Tuya A, Bayarsaikhan S, Dorjsuren A, Mandakh U, Bao Y, Vanchindorj B. Variations and climate constraints of terrestrial net primary productivity over Mongolia. Quaternary International. 2020; 537: 112-125. https://doi.org/10.1016/j.quaint.2019.06.017.

6. Zhang C, Wu S, Leng G. Possible NPP changes and risky ecosystem region identification in China during the 21 st century based on BCC-CSM2. Journal of Geographical sciences. 2020; 30(8): 1219-1232. https://doi.org/10.1007/s11442-020-1778-8.

7. Lewis SL, Wheeler CE. Regenerate natural forests to store carbon. Nature. 2019; 568: 25-

28. https://www.nature.com/articles/d41586-019-01026-8.

8. Wood A, Tolera M, Snell M, O'Hara P, Hailu A. Community forest management (CFM) in south-west Ethiopia: Maintaining forests, biodiversity and carbon stocks to support wild coffee conservation. Global Environmental Change. 2019; 59: 101980. https://doi.org/10.1016/j.gloenvcha.2019.101980.

9. FAO, 2020. Global Forest Resources Assessment, 2020.

10. Zhang J, Ge Y, Chang J, Jiang B, Jiang H, Peng CH, Zhu JR, Yuan WG, Qi LZ, Yu SQ. Carbon storage by ecological service forests in Zhejiang Province, subtropical China. Forest Ecology and Management. 2007; 245(1): 64-

75. https://doi.org/10.1016/j.foreco.2007.03.042.

11. Ouyang S, Xiang WH, Gou MM, Chen L, Lei PF, Xiao WF, Deng XW, Zeng LX, Li JR, Zhang T, Peng CH, Forrester DI, Meyer C. Stability in subtropical forests: The role of tree species diversity, stand structure, environmental and socio-economic conditions. Global Ecology and Biogeography. 2021; 30: 500-513. https://doi.org/10.1111/geb.13235.

12. Seedre M, Janda P, Trotsiuk V, Hedwall PO, Morrissey RC, Mikoláš M, Bače R, Čada V, Svoboda M. Biomass carbon accumulation patterns throughout stand development in primary uneven-aged forest driven by mixed-severity natural disturbances. Forest Ecology and Management. 2020; 455: 117676. https://doi.org/10.1016/j.foreco.2019.117676.

13. Ouyang S, Xiang WH, Wang XP, Xiao WF, Chen L, Li SG, Sun H, Deng XW, Forrester DI, Zeng LX, Lei PF, Lei XD, Gou MM, Peng CH. Effects of stand age, richness and density on productivity in subtropical forests in China. Journal of Ecology. 2019; 107: 22662277. https://doi.org/10.1111/1365-2745.13194.

14. Xu L, Shi YJ, Fang HY, Zhou GM, Xu XJ, Zhou YF, Tao JX, Ji B., Xu J, Li C, Chen L. Vegetation carbon stocks driven by canopy density and forest age in subtropical forest ecosystems. Science of the Total Environment. 2018; 631-632: 619-

626. https://doi.org/10.1016/j.scitotenv.2018.03.080.

15. Wang SQ, Zhou L, Chen JM, Ju WM, Feng XF, Wu WX. Relationships between net primary productivity and stand age for several forest types and their influence on China's carbon balance. Journal of Environmental Management. 2011; 92: 16511662. https://doi.org/10.1016/j.jenvman.2011.01.024.

16. Zheng ZT, Zhu WQ, Zhang YJ. Seasonally and spatially varied controls of climatic factors on net primary productivity in alpine grasslands on the Tibetan Plateau. Global Ecology and Conservation. 2020; 21 : e00814. https://doi.org/10.1016/j.gecco.2019.e00814.

17. Cheng J, Lee X, Theng BKG, Zhang L, Fang B, Li F. Biomass accumulation and carbon sequestration in an age-sequence of Zanthoxylum bungeanum plantations under the Grain for Green Program in karst regions, Guizhou province. Agricultural and Forest Meteorology. 2015; 203: 88-95. https://doi.org/10.1016/j.agrformet.2015.01.004. 
18. Ryan MG, Binkley D, Fownes JH. Age-related decline in forest productivity: pattern and process. In: M. Begon and A.H. Fitter, Advances in Ecological Research. Academic Press. 1997; pp. 213-262. https://doi.org/10.1016/S0065-2504(08)60009-4.

19. Chen B, Zhang X, Tao J, Wu J, Wang J, Shi P, Yu C. The impact of climate change and anthropogenic activities on alpine grassland over the Qinghai-Tibet Plateau. Agricultural and Forest Meteorology. 2014; 189-190: 11-

18. http://dx.doi.org/10.1016/j.agrformet.2014.01.002.

20. Xie Y, Wang H, Lei X. Simulation of climate change and thinning effects on productivity of Larix olgensis plantations in northeast China using 3-PG mix model. Journal of Environmental Management. 2020; 261: 110249-

110249. https://doi.org/10.1016/j.jenvman.2020.110249.

21. IPCC. Climate change 2013: the physical science basis. Near-term Climate Change: Projections and Predictability.

22. Laflower DM, Hurteau MD, Koch GW, North MP, Hungate BA. Climate-driven changes in forest succession and the influence of management on forest carbon dynamics in the Puget Lowlands of Washington State, USA. Forest Ecology and Management. 2016; 362: 194-204. https://doi.org/10.1016/j.foreco.2015.12.015.

23. Wu C, Chen D, Shen J, Sun X, Zhang S. Estimating the distribution and productivity characters of Larix kaempferi in response to climate change. Journal of Environmental Management. 2021; 280: 111633.https://doi.org/10.1016/j.jenvman.2020.111633.

24. Sherry RA, Weng ES, Arnone III JA, Johnson DW, Schimel DS, Verburg PS, Wallace LL, Luo YQ. Lagged effects of experimental warming and doubled precipitation on annual and seasonal aboveground biomass production in a tallgrass prairie. Global Change Biology. 2008; 14: 2923-2936. https://doi.org/10.1111/j.1365-2486.2008.01703.x.

25. Teng MJ, Zeng LX, Hu WJ, Wang PC, Yan ZG, He W, Zhang Y, Huang ZL, Xiao WF. The impacts of climate changes and human activities on net primary productivity vary across an ecotone zone in Northwest China. Science of the Total Environment. 2020; 714: 136691-136691. https://doi.org/10.1016/j.scitotenv.2020.136691.

26. Xu C, Liu M, An S, Chen JM, Yan P. Assessing the impact of urbanization on regional net primary productivity in Jiangyin County, China. Journal of Environmental Management. 2007; 85(3): 597-606. https://doi.org/10.1016/j.jenvman.2006.08.015.

27. Lei XD, Yu L, Hong LX. Climate-sensitive integrated stand growth model (CS-ISGM) of Changbai larch (Larix olgensis) plantations. Forest Ecology and Management. 2016; 376: 265-275. https://doi.org/10.1016/j.foreco.2016.06.024.

28. Dai E, Wu Z, Ge Q, Xi W, Wang X. Predicting the responses of forest distribution and aboveground biomass to climate change under RCP scenarios in southern China. Global Change Biology. 2016; 22: 3642-

3661. https://onlinelibrary.wiley.com/doi/10.1111/gcb.13307.

29. Gupta R, Sharma LK. The process-based forest growth model 3-PG for use in forest management: A review. Ecological Modelling. 2019; 397: 55-73. https://doi.org/10.1016/j.ecolmodel.2019.01.007.

30. Xie Y, Wang H, Lei X. Application of the 3-PG model to predict growth of Larix olgensis plantations in northeastern China. Forest Ecology and Management. 2017; 406: 208-218. https://doi.org/10.1016/j.foreco.2017.10.018.

31. Bossel H. TREEDYN3 forest simulation model. Ecological Modelling. 1996; 90: 187-227. https://doi.org/10.1016/03043800(95)00139-5.

32. Gilmanov TG, Parton WJ, Ojima DS. Testing the 'CENTURY' ecosystem level model on data sets from eight grassland sites in the former USSR representing a wide climatic/soil gradient. Ecological Modelling. 1997; 96: 191-210. https://doi.org/10.1016/S03043800(96)00067-1.

33. Wang F, Mladenoff DJ, Forrester JA, Keough C, Parton WJ. Global sensitivity analysis of a modified CENTURY model for simulating impacts of harvesting fine woody biomass for bioenergy. Ecological Modelling. 2013; 259: 16-

23. https://doi.org/10.1016/j.ecolmodel.2013.03.008.

34. Peng CH, Liu JX, Dang QL, Apps MJ, Jiang H. TRIPLEX: a generic hybrid model for predicting forest growth and carbon and nitrogen dynamics. Ecological Modelling. 2002; 153: 109-130. https://doi.org/10.1016/S0304-3800(01)00505-1.

35. Peng CH, Zhou XL, Zhao SQ, Wang XP, Zhu B, Piao SL, Fang JY. Quantifying the response of forest carbon balance to future climate change in Northeastern China: Model validation and prediction. Global and Planetary Change. 2009; 66: 179194. https://doi.org/10.1016/j.gloplacha.2008.12.001.

36. Zhao MF, Xiang WH, Deng XW, Tian DL, Huang ZH, Zhou XL, Yu GR, He HL, Peng CH. Application of TRIPLEX model for predicting Cunninghamia lanceolata and Pinus massoniana forest stand production in Hunan Province, southern China. Ecological Modelling. 2013; 250: 58-71. https://doi.org/10.1016/j.ecolmodel.2012.10.011.

37. Zhang J, Chu ZY, Ge Y, Zhou XL, Jiang H, Chang J, Peng CH, Zheng JW, Jiang B, Zhu JR, Yu SQ,. TRIPLEX model testing and application for predicting forest growth and biomass production in the subtropical forest zone of China's Zhejiang Province.

Page $12 / 19$ 
Ecological Modelling. 2008; 219(3): 264-275. https://doi.org/10.1016/j.ecolmodel.2008.07.016.

38. Zhou XL, Peng CH, Dang QL. Assessing the generality and accuracy of the TRIPLEX model using in situ data of boreal forests in central Canada. Environmental Modelling \& Software. 2004; 19(1): 35-46. https://doi.org/10.1016/S1364-8152(03)00108-7.

39. Lin D, Lai J, Muller-Landau HC, Mi X, Ma K. Topographic variation in aboveground biomass in a subtropical evergreen broadleaved forest in China. PLoS ONE. 2012; 7: e48244. https://doi.org/10.1371/journal.pone.0048244.

40. McEwan RW, Lin YC, Sun IF, Hsieh CF, Su SH, Chang LW, Michael Song GZ, Wang HH, Hwong JL, Lin KC, Yang KC, Chiang JM. Topographic and biotic regulation of aboveground carbon storage in subtropical broad-leaved forests of Taiwan. Forest Ecology and Management. 2011; 262: 1817-1825. https://doi.org/10.1016/j.foreco.2011.07.028.

41. Xu YZ, Franklin SB, Wang QG, Shi Z, Luo YQ, Lu ZJ, Zhang JX, Qiao XJ, Jiang MX. Topographic and biotic factors determine forest biomass spatial distribution in a subtropical mountain moist forest. Forest Ecology and Management. 2015; 357: 95103. https://doi.org/10.1016/j.foreco.2015.08.010.

42. Tilman D, Lehman CL, Thomson KT. Plant diversity and ecosystem productivity: theoretical considerations. Proceedings of the National Academy of Sciences. 1997; 94: 1857-1861. https://doi.org/10.1073/pnas.94.5.1857.

43. Xiang WH, Fang X. Community structure and soil properties in subtropical secondary forests. Beijing: Science Press (in Chinese); 2018.

44. Ngo KM, Turner BL, Muller-Landau HC, Davies SJ, Larjavaara M, Nik H, Nik FB, Lum S. Carbon stocks in primary and secondary tropical forests in Singapore. Forest Ecology and Management. 2013; 296: 81-89. http://dx.doi.org/10.1016/j.foreco.2013.02.004.

45. Van Tuyl S, Law BE, Turner DP, Gitelman Al. Variability in net primary production and carbon storage in biomass across Oregon forests-an assessment integrating data from forest inventories, intensive sites, and remote sensing. Forest Ecology and Management. 2005; 209: 273-291. https://doi.org/10.1016/j.foreco.2005.02.002.

46. Wang G, Guan D, Xiao L, Peart MR. Forest biomass-carbon variation affected by the climatic and topographic factors in Pearl River Delta, South China. Journal of Environmental Management. 2019; 232: 781-788. https://doi.org/10.1016/j.jenvman.2018.11.130.

47. Ren Y, Chen SS, Wei XH, Xi WM, Luo YJ, Song XD, Zuo SD, Yang YS. Disentangling the factors that contribute to variation in forest biomass increments in the mid-subtropical forests of China. Journal of Forestry Research. 2016; 27: 919 930. https://doi.org/10.1007/s11676-016-0237-y.

48. Wang WJ, He HS, Thompson FR, Fraser JS, Dijak WD. Changes in forest biomass and tree species distribution under climate change in the northeastern United States. Landscape Ecology. 2017; 32: 1399-1413. https://doi.org/10.1007/s10980-016-0429-z.

49. Wu Z, Dai E, Wu Z, Lin M. Assessing differences in the response of forest aboveground biomass and composition under climate change in subtropical forest transition zone. Science of the Total Environment. 2020; 706: 135746. https://doi.org/10.1016/j.scitotenv.2019.135746.

50. Bayer AD, Pugh TAM, Krause A, Arneth A. Historical and future quantification of terrestrial carbon sequestration from a GreenhouseGas-Value perspective. Global Environmental Change. 2015; 32: 153-164. http://dx.doi.org/10.1016/j.gloenvcha.2015.03.004.

51. Guo B, Zang WQ, Luo W. Spatial-temporal shifts of ecological vulnerability of Karst Mountain ecosystem-impacts of global change and anthropogenic interference. Science of the Total Environment. 2020; 741: 140256-

140256. https://doi.org/10.1016/j.scitotenv.2020.140256.

52. Luo DW, Huang JG, Jiang XY, Ma QQ, Liang HX, Guo XL, Zhang SK. Effect of climate and competition on radial growth of Pinus massoniana and Schima superba in China's subtropical monsoon mixed forest. Dendrochronologia (Verona). 2017; 46: 2434. http://dx.doi.org/doi:10.1016/j.dendro.2017.08.001.

53. Piao SL, Fang JY, Zhou LM, Zhu B, Tan K, Tao S. Changes in vegetation net primary productivity from 1982 to 1999 in China. Global Biogeochemical Cycles. 2005; 19: GB2027.1-GB2027.16. https://doi.org/10.1029/2004GB002274.

54. Tang XL, Wang YP, Zhou GY, Zhang DQ, Liu S, Liu SZ, Zhang QM, Liu JX, Yan JH. Different patterns of ecosystem carbon accumulation between a young and an old-growth subtropical forest in Southern China. Plant Ecology. 2011; 212: 13851395. https://doi.org/10.1007/s11258-011-9914-2.

55. Chen XY, Mulder J. Atmospheric deposition of nitrogen at five subtropical forested sites in South China. Science of the Total Environment. 2007; 378: 317-30. https://doi.org/10.1016/j.scitotenv.2007.02.028.

56. NFGA, 2020. Technical regulations for continuous forest inventory. GB/T 38590-2020.

57. Landsberg JJ, Waring RH. A generalised model of forest productivity using simplified concepts of radiation-use efficiency, carbon balance and partitioning. Forest Ecology and Management. 1997; 95: 209-228. https://doi.org/10.1016/S0378-1127(97)00026-1. 
58. Parton WJ, Scurlock JMO, Ojima DS, Gilmanov TG, Scholes RJ, Schimel DS, Kirchner T, Menaut J-C, Seastedt T, Garcia Moya E, Kamnalrut A, Kinyamario Jl. Observations and modeling of biomass and soil organic matter dynamics for the grassland biome worldwide. Global Biogeochemical Cycles. 1993; 7: 785-809. https://doi.org/10.1029/93GB02042.

59. Zhang H, Song TQ, Wang KL, Wang GX, Liao JX, Xu GH, Zeng FP. Biogeographical patterns of forest biomass allocation vary by climate, soil and forest characteristics in China. Environmental Research Letters. 2015; 10(4): 44014. https://doi.org/10.1088/17489326/10/4/044014.

60. Lei XD, Tang MP, Lu YC, Hong LX, Tian DL. Forest Inventory in China: Status and Challenges. International Forestry Review. 2009; 11: 52-63.

61. Fang JY, Chen AP, Peng CH, Zhao SQ, Ci LJ. Changes in forest biomass carbon storage in China between 1949 and 1998 . Science. 2001; 292: 2320-2322. http://www.jstor.org/stable/3083885.

62. Lin DM, Lai JS, Mi XC, Ren HB, Ma KP. Spatial variation in community structure of a subtropical evergreen broad-leaved forest: Implications for sampling design. Chinese Science Bulletin. 2013; 58: 1181-1186. https://doi.org/10.1007/s11434-012-5586-0.

63. Xiang WH, Liu SH, Deng XW, Shen AH, Lei XD, Tian DL, Zhao MF, Peng CH. General allometric equations and biomass allocation of Pinus massoniana trees on a regional scale in southern China. Ecological Research. 2011; 26: 697-

711. https://doi.org/10.1007/s11284-011-0829-0.

64. Zhao MF, Xiang WH, Peng CH, Tian DL.. Simulating age-related changes in carbon storage and allocation in a Chinese fir plantation growing in southern China using the 3-PG model. Forest Ecology and Management. 2009; 257(6): 15201531. https://doi.org/10.1016/j.foreco.2008.12.025.

\section{Figures}

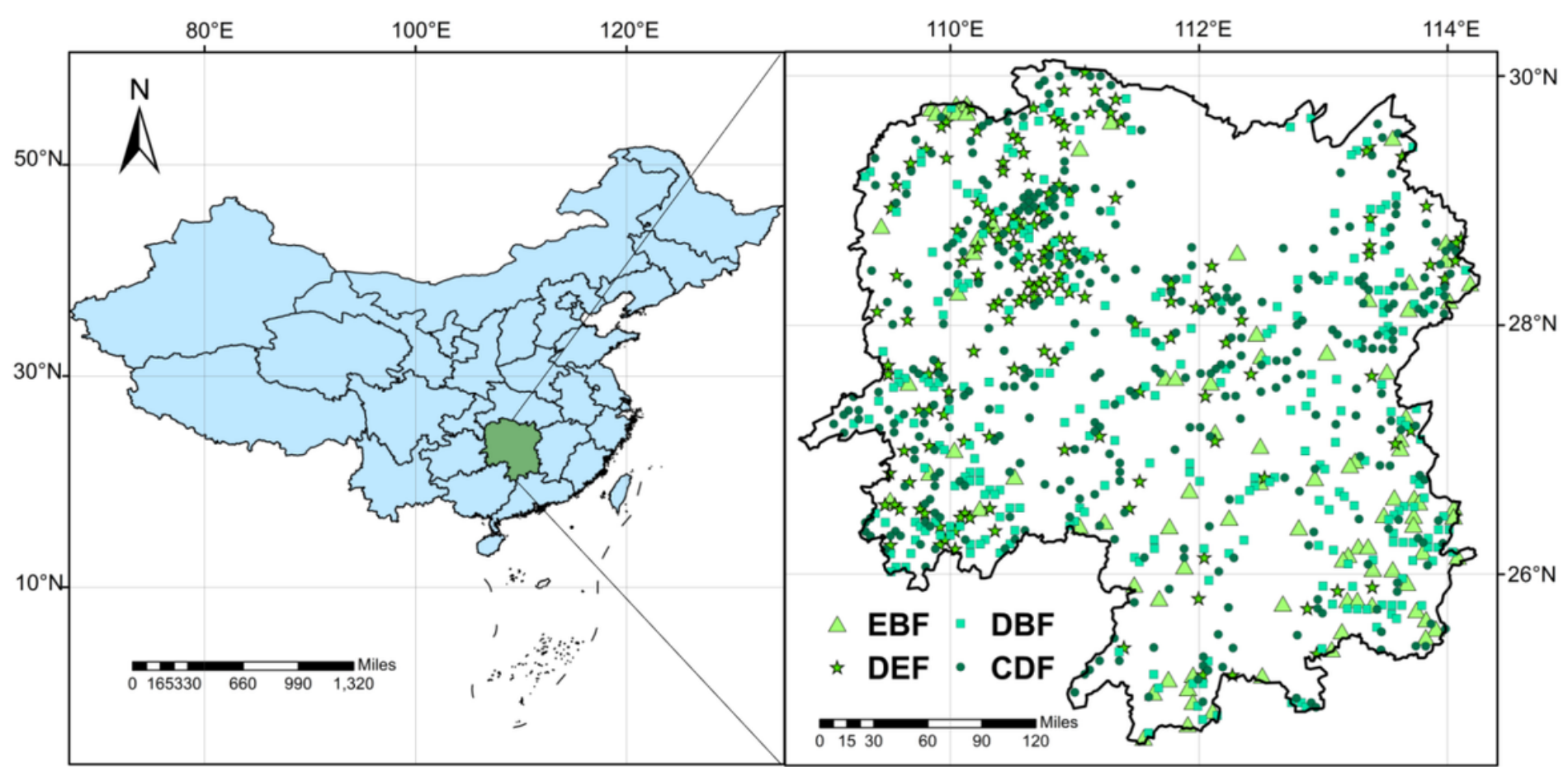

\section{Figure 1}

The spatial distribution of 875 permanent sample plots (PSP) with 93 PSP in evergreen broad-leaved forest (EBF), 267 PSP in deciduous and evergreen broad-leaved mixed forest (DEF), 155 PSP in deciduous broad-leaved forest (DBF), and 360 PSP in conifer and broadleaved mixed forest (CDF) in Hunan Province, southern China, respectively (modified in 2014). 

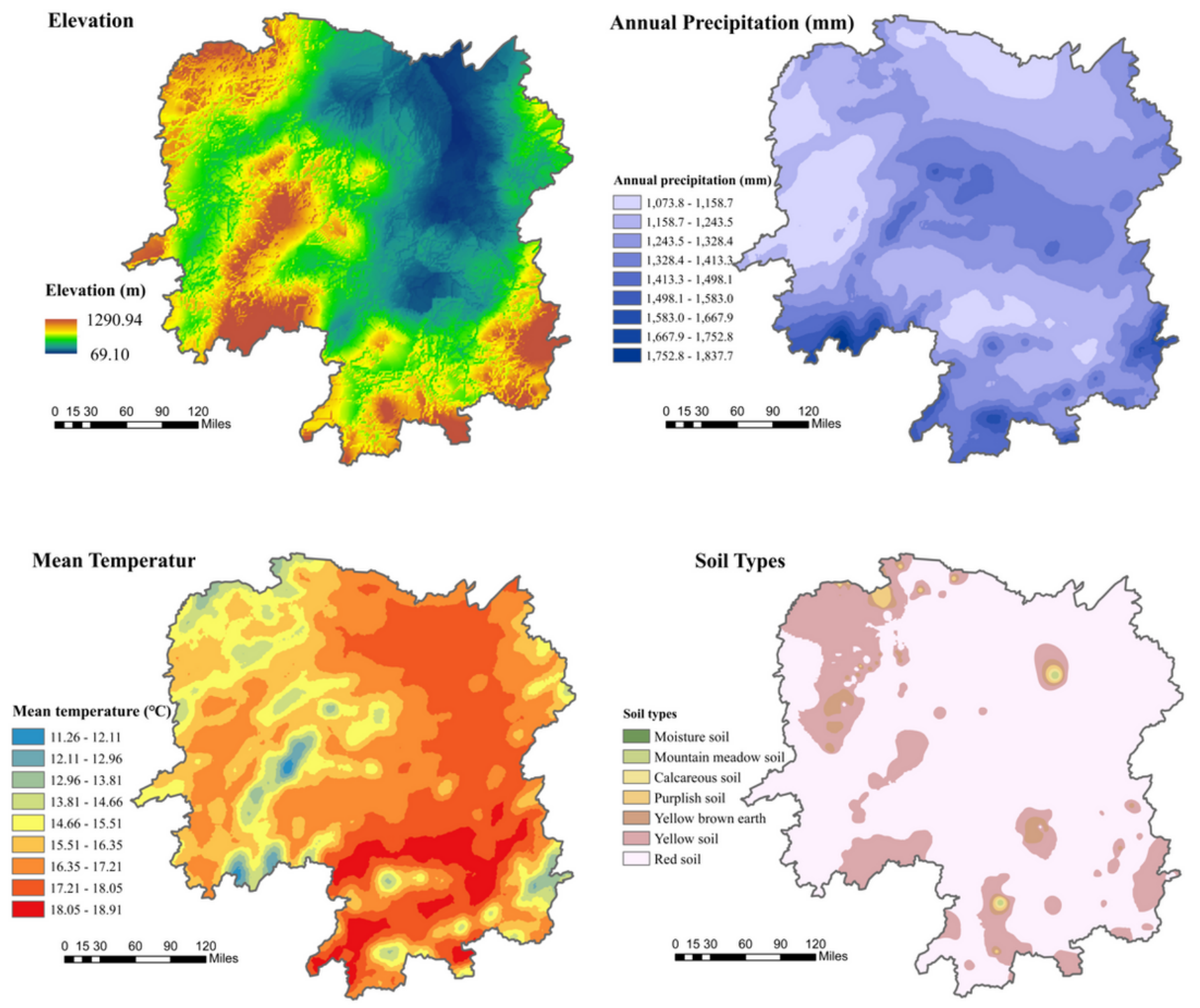

\section{Figure 2}

Maps showing variation in elevation, annual precipitation, annual average temperature, and soil types in Hunan Province. 


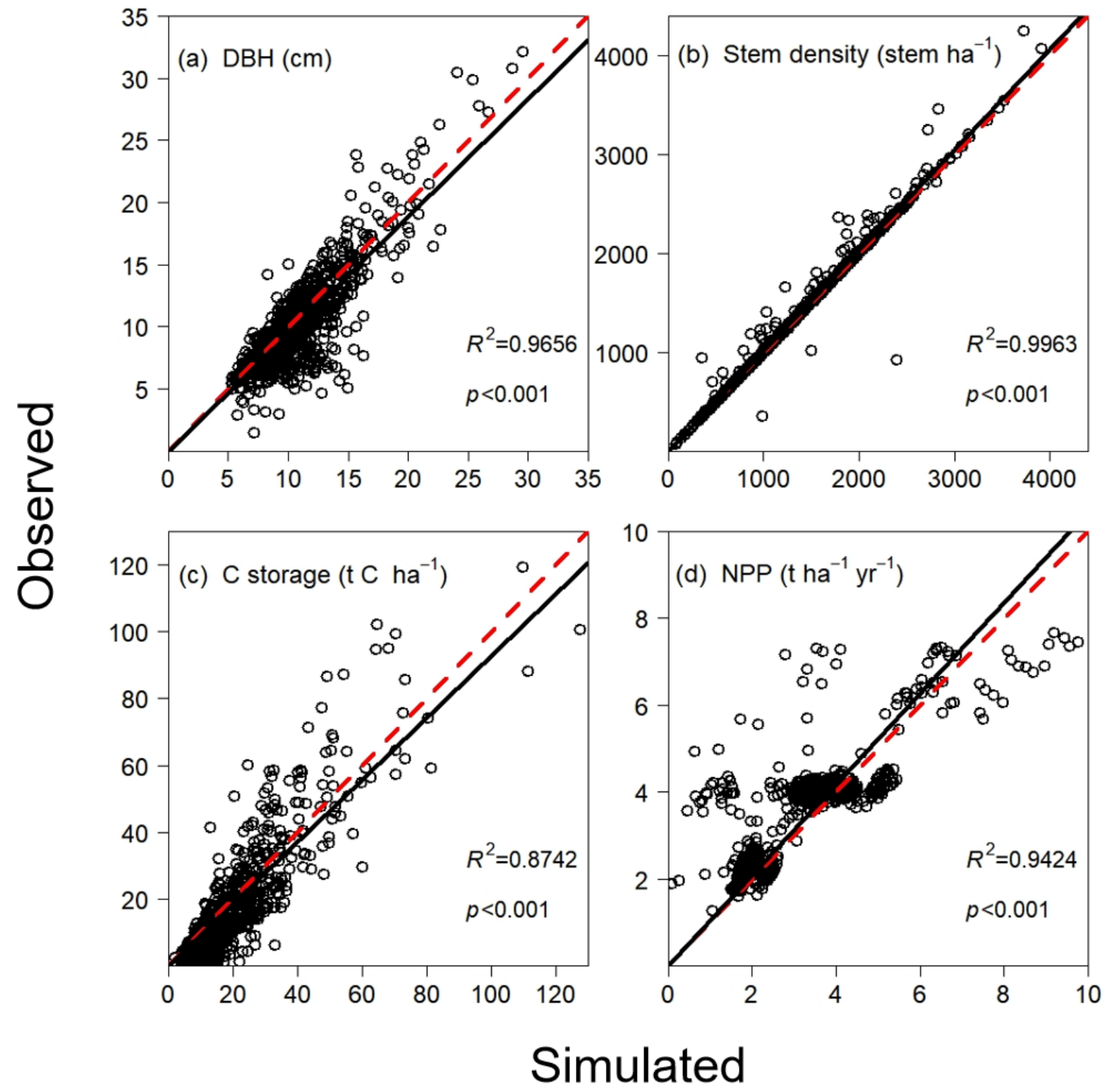

Figure 3

Comparison between the simulated and observed values of (a) DBH (cm); (b) stem density (stem ha-1); (c) C storage (t C ha-1), and (d) NPP (t ha-1 yr-1). 

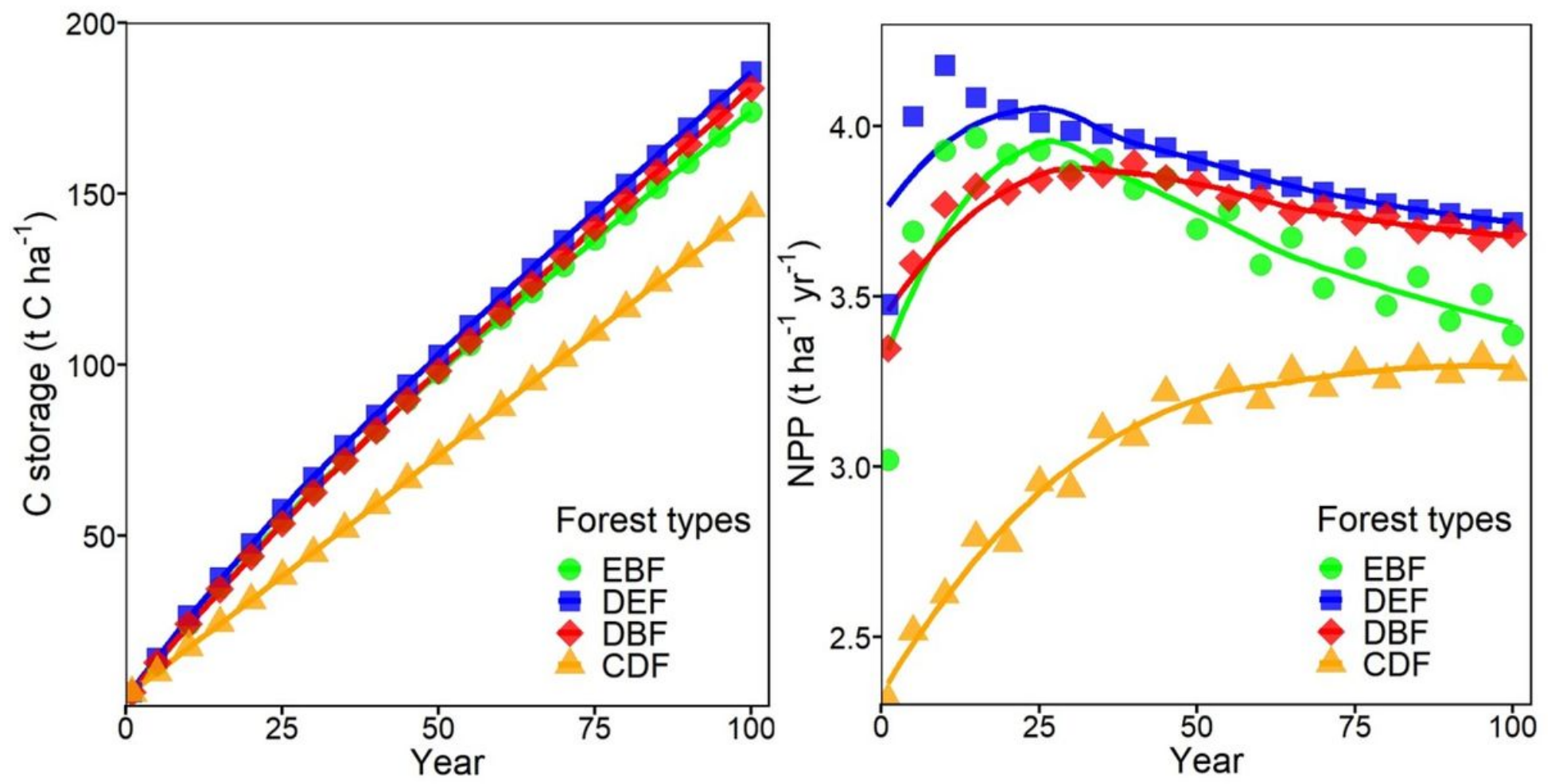

Figure 4

Dynamics of predicted stand $\mathrm{C}$ storage ( $\mathrm{C}$ ha-1) and NPP ( $\mathrm{t}$ ha-1 $\mathrm{yr}-1$ ) by the TRIPLEX1.6 model among subtropical secondary forests over time (within 100 years). EBF = evergreen broad-leaved forest, $\mathrm{DEF}=$ deciduous and evergreen broad-leaved mixed forest, $\mathrm{DBF}=$ deciduous and evergreen broad-leaved forest, and CDF = coniferous and broad-leaved mixed forest. 

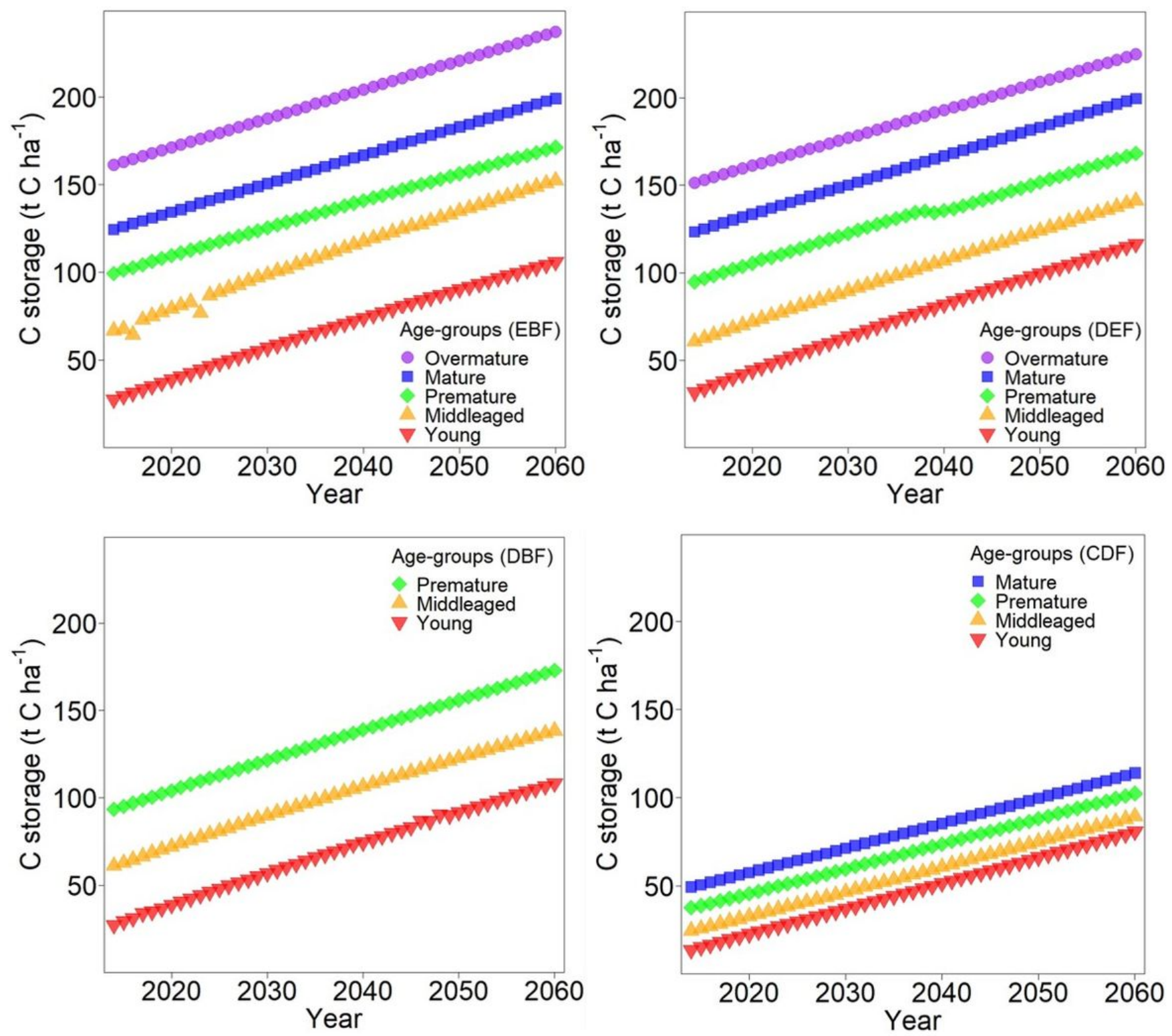

Figure 5

Changes in predicted stand C storage (t C ha-1) for different age-groups of subtropical secondary forests from 2014 to 2026: (a) evergreen broad-leaved forest; (b) deciduous and evergreen broad-leaved mixed forests; (c) deciduous broad-leaved forest; and (d) coniferous and broad-leaved mixed forest. 

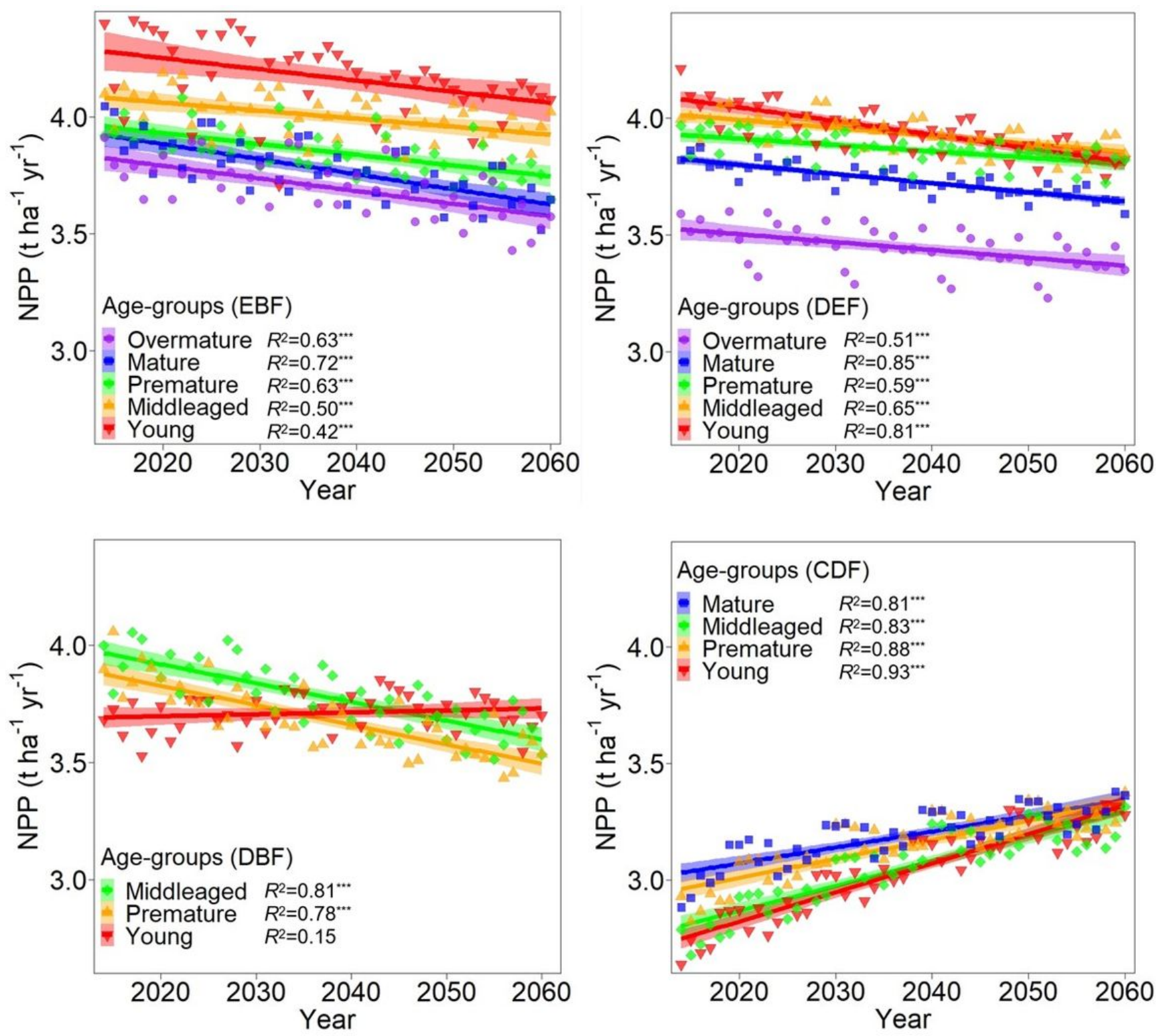

Figure 6

Changes in predicted NPP (t ha-1 yr-1) for different age-groups of subtropical secondary forests from 2014 to 2026: (a) evergreen broadleaved forest; (b) deciduous and evergreen broad-leaved mixed forests; (c) deciduous broad-leaved forest; and (d) coniferous and broadleaved mixed forest. Solid regression lines indicate a significant relationship; $95 \%$ confidence intervals are indicated by shading.

\section{Supplementary Files}

This is a list of supplementary files associated with this preprint. Click to download.

- CstorageandNPP20211029Additionalfile.doc 